\title{
Unusually dislodged tracheostomy tube with intact airway
}

\author{
Bharat Hosur (ㄷ, , Chirag Kamal Ahuja 지, ${ }^{1}$ Ramandeep Singh Virk, ${ }^{2}$ \\ Paramjeet Singh (1) ${ }^{1}$
}

${ }^{1}$ Radiodiagnosis, Post Graduate Institute of Medical Education and Research, Chandigarh, India ENT, Post Graduate Institute of Medical Education and Research, Chandigarh, India

Correspondence to Dr Chirag Kamal Ahuja; chiragkahuja@rediffmail.com

Accepted 24 June 2020

Check for updates

(c) BMJ Publishing Group Limited 2020. No commercial re-use. See rights and permissions. Published by BMJ.

To cite: Hosur B, Ahuja CK, Virk RS, et al. BMJ Case Rep 2020;13:e237195. doi:10.1136/bcr-2020237195

\section{DESCRIPTION}

A 35-year-old male patient, tracheostomised for about 10 years, presented to our hospital with a dyspnoea of 2 days duration. There was a history of accidental decannulation of the tracheostomy tube recently. The cause for initial tracheostomy performed about a decade back was a subglottic stenosis following a prolonged intubation in an episode of scrub typhus with altered sensorium. Patient was however lost to follow-up after a few months of initial tracheostomy.

On evaluation, a stenosed stoma was seen at the tracheostomy site with no tube being visible externally. Suspecting accidental extubation, the stoma was revised for $7.5 \mathrm{~mm}$ cuffed tracheostomy tube and supportive management was initiated. The emergency chest radiograph had significant motion artefacts and hence unremarkable. Next day, the tracheostomy tube fixation was performed as planned with an endpoint of non-dyspnoeic clinical status. A non-contrast CT chest and neck (figure 1) with virtual bronchoscopy was done to assess the airway status. The freshly instilled tracheostomy tube was in situ. However, another tracheostomy tube was seen caudal to it contiguously from the internal opening of the fresh tube, snugly approximating to its orifice, inferiorly, its extent was beyond the carina, for up to $3 \mathrm{~cm}$ into the left main bronchus. On the three-dimensional volumerendered images (figure 2), there was a left-sided kink in the caudal tracheostomy tube at the carina with a focal breech on the opposite side. Both the left and right main bronchi had patent airways communicating through the end of the conduit and broken part of the tube, respectively. No pulmonary lobar collapse or consolidation was noted on either side. The management team was alerted about the dislodged and fractured old tube across the carina with a patent airway and a new tracheostomy tube in situ.

Dislodgement of tracheostomy tube is considered to be rare, with an incidence of $<1 / 1000$ tracheostomy tube days. ${ }^{1}$ Although the incidence is low, a high risk of mortality is commonly associated due to severe airway compromise. Many times, the tube is suspended in trachea or even displaced cranially or caudally due to active force generated by coughing. ${ }^{23}$ Major factors for decision-making in a displaced tracheostomy tube are respiratory distress of the patient at presentation, type of the tube and extent of its dislodgement and the need for resecuring of the airway. ${ }^{4}$ Translaryngeal or transstomal oxygenation and intubation is immediately ensued

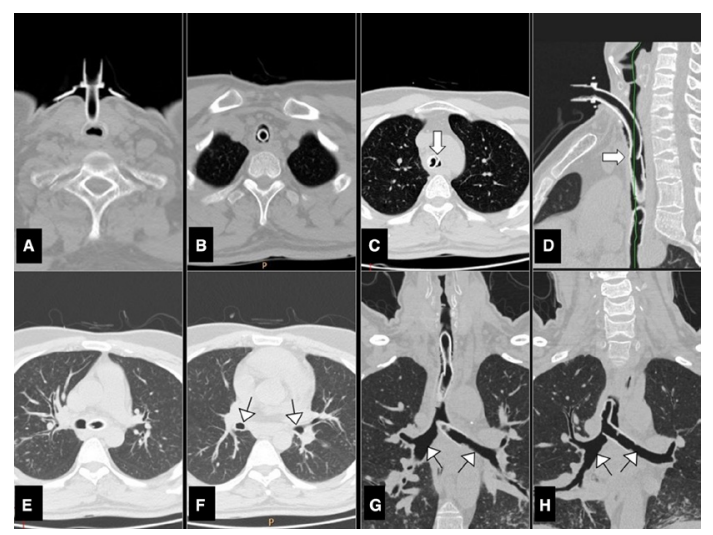

Figure 1 Non-contrast $C T$ chest-axial ( $A-C, E$ and $F)$, sagittal (D) and coronal ( $G$ and $H$ ) images showing the freshly placed tracheostomy tube in situ and displaced old tracheostomy tube with closely approximated openings (thick arrow). Bilateral main bronchi (thin arrows) are patent with adequate air column across the end of the previous tube (towards the left) and a focal breach towards the right leading to aeration of the right-sided bronchial tree.

to optimise respiratory status. Role of imaging commences once the patient is rendered free from respiratory distress and/or airway is secured. Our patient fortunately had a fracture in the displaced tracheostomy tube across the carina, without bronchial airway compromise on either side which is hitherto unreported to the best of our knowledge.

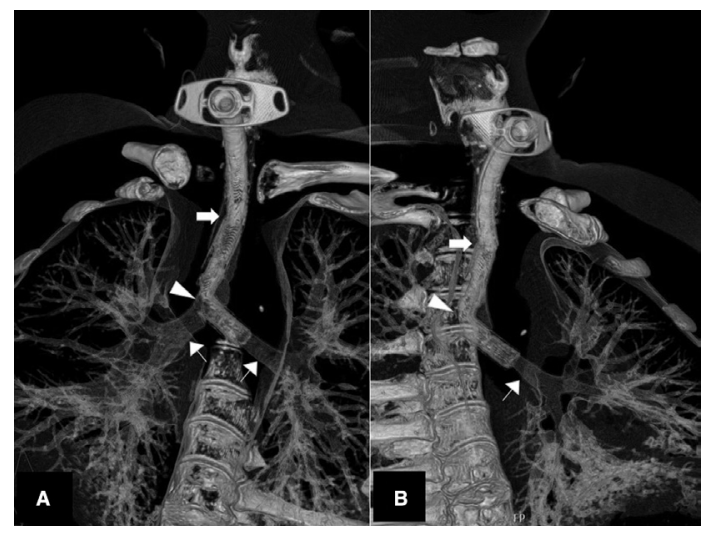

Figure 2 Three-dimensional volume-rendered images in oblique coronal views ( $A$ and $B$ ) showing contiguity of in situ and displaced tracheostomy tubes (thick arrow), focal breach on opposite side of kink in the old tube (arrow head) and patent airway within bilateral main bronchi (thin arrows). 


\section{Learning points}

It is essential to maintain strict vigil in tracheostomised patients about the care of the tracheostomy site with preemptive tube changes advocated in any risk of displacement.

- The imaging in management of tracheostomy tube dislodgement is of paramount importance, irrespective of the clinical status or relief of respiratory distress.

Imaging plays a vital role by alarming the management team about the status of airway patency, pulmonary parenchyma and procedural complications like false tracks and vascular or pulmonary injury.

Contributors BH: conduct and reporting of the work. CKA: planning, conduct and editing. RSV: clinical patient management and editing of the manuscript. PS: manuscript editing and guarantor.
Funding The authors have not declared a specific grant for this research from any funding agency in the public, commercial or not-for-profit sectors.

Competing interests None declared.

Patient consent for publication Obtained.

Provenance and peer review Not commissioned; externally peer reviewed.

\section{ORCID iDs}

Bharat Hosur http://orcid.org/0000-0002-8622-3824

Chirag Kamal Ahuja http://orcid.org/0000-0003-0734-3252

Paramjeet Singh http://orcid.org/0000-0002-3340-0751

\section{REFERENCES}

1 Rajendram R, Khan M, Joseph A. Tracheostomy tube displacement: an update on emergency airway management. Indian J Respir Care 2017;6:800-6.

2 Seay SJ, Gay SL. Problem in tracheostomy patient care: recognizing the patient with a displaced tracheostomy tube. ORL Head Neck Nurs 1997;15:10-11.

3 Krishnamurthy A, Vijayalakshmi R. Broken tracheostomy tube: a fractured mandate. J Emerg Trauma Shock 2012;5:97-9.

4 Parida PK, Kalaiarasi R, Gopalakrishnan S, et al. Fractured and migrated tracheostomy tube in the tracheobronchial tree. Int J Pediatr Otorhinolaryngol 2014;78:1472-5.

Copyright 2020 BMJ Publishing Group. All rights reserved. For permission to reuse any of this content visit

https://www.bmj.com/company/products-services/rights-and-licensing/permissions/

BMJ Case Report Fellows may re-use this article for personal use and teaching without any further permission.

Become a Fellow of BMJ Case Reports today and you can:

- Submit as many cases as you like

- Enjoy fast sympathetic peer review and rapid publication of accepted articles

- Access all the published articles

Re-use any of the published material for personal use and teaching without further permission

Customer Service

If you have any further queries about your subscription, please contact our customer services team on +44 (0) 2071111105 or via email at support@bmj.com.

Visit casereports.bmj.com for more articles like this and to become a Fellow 